\title{
Policies, Pattern and Marketing Determinants of Handloom Exports from India
}

\author{
Mohammad Zohair *
}

\begin{abstract}
Handloom is one of the oldest existing industries in India, which had attained a high degree of recognition in the world market for the textiles requirements through the ages. It is known for its employment potential to the rural population, product varieties and unmatched craftsmanship. After globalisation, the industry is facing variety of challenges. The present study is an attempt to review the policy initiatives and institutional framework established by the Government of India. Further the export performance of the sector is analysed. An attempt has also been made to look at the problem from a marketing perspective by using multiple regression analysis. It also suggests the export marketing strategies to the firms engaged in export of handloom goods. The growth and prosperity of such firms will ensure the prosperity of the handloom weavers, who are the most important stakeholders of this decentralised industry.
\end{abstract}

Keywords: Exports; Handloom; India; Marketing Strategy

\subsection{Introduction}

The handloom industry of India is among the oldest and great manufacturing institutions of the world. It demonstrates the richness and diversity of Indian culture along with artistry of weavers. Indian handloom industry is deeply rooted in our social, economic and cultural life. The handloom fabrics with intricate design, vibrant colours and also depicting the regional as well a cultural specialty cannot be replicated on mechanized looms. The industry, which provides employment to substantial number of rural and semi-urban people is highly disintegrated and spreads across the country. It is an important source of textile production along with mill and powerloom sector. As India has been a major exporter of handloom products, there is a need to develop an appropriate approach to export of handloom that can enhance its performance.

* Assistant Professor of Management, School of Business Studies, Central University of Karnataka, Gulbarga, Karnataka. 
In the post-Independence India, handloom remained an important source of livelihood for large population of this country after agriculture. It provides employment to about 3.85 million weaving families across the nation which includes full time as well as partial employment of agrarian population (NCAER, 2009-10). In addition to the direct dependence, manifold depend indirectly. It helps in checking the migration of farmers to urban centers by providing an alternative source of livelihood during the period when usually there is no agriculture activity in the fields. It is a large industry in aggregate; largely rural and semi-urban. Like other traditional industries, handloom industry too is not capital intensive, suited to the environment, uses locally available raw materials and renewable energies and produce large quantities of output from large number of small and dispersed units. The technological skills involve large number of people and are easily propagated through generations. These technologies are embedded in their societal context, with in-built systems for skill dissemination.

Moreover, unlike modern employment system, it engages the whole family, thereby creating an emotional bondage of interdependency for holding the family members together. Further, weavers are the artists who put their mind in every thread of the fabric. They are the artists who make mulmul, that was so thin that the entire saree could pass through a ring; brocade, where very intricate designs are woven with perfection; and ikat, where designs are created by the very dyeing of warp and weft yarn itself, a few mentioned here from a long list of artistic weaving varieties.

The handloom industry is dispersed nationwide as some kinds of hand weaving activities are present everywhere with variation in product range, uniqueness of products and manufacturing technique etc. Weavers of different parts of the country are skilled and specialized for weaving different varieties which are the distinctions of the cluster. Some places attained eminence through the ages. There are many handloom production centres throughout the country where handloom is the chief economic activity even today where a large number of people are engaged in production, domestic trading and in some cases export of handloom goods. A few of the famous varieties are brocade of Banaras, ikat of Pochampally, patola of Patan and Kanchipuram silk etc. The product range includes conventional items such as sarees, dhotis and lungis to the items of modern living needs such as furnishing, dress material and clothing etc. From these centres handloom production, now, constitute about 15 per cent of the country's total textile production, which had been much higher earlier. The total handloom cloth production in India reached 6.9 billion square meters in 2012-13, up from 6.6 billion square meters in 2008-09 (www.ibef.org).

At present the handloom sector contributes significantly to the foreign exchange earnings through its exports. In addition to fulfilling the substantial portion of clothing 
requirement of the country, Indian handloom has attained international reputation since long and the products are still liked and admired in USA, Japan and European countries. The major handloom export clusters are Karur \& Madurai in Tamil Nadu, Kannur in Kerala and Panipat in Haryana. While the exportable handloom products like tablemats, placemats, embroidered textile materials, curtains, floor mats etc. are produced in Karur, Madurai \& Kannur, Panipat is famous for durries and other heavy varieties where handspun yarn is heavily used. Besides this, other centres like Khekhra and Varanasi in U.P., Bhagalpur in Bihar, Shantipur in West Bengal, Jaipur in Rajasthan, Ahmedabad in Gujarat, Warangal and Chirala in Andhra Pradesh, Pochampally in Telangana, and Sambhalpur in Orissa also contribute significantly to the handloom exports. These production centres have developed their potential in exporting of specialised products. Chennai, Delhi, Mumbai and Kolkata are having large concentration of merchant exporters who source their products from these centres. Shirting, home furnishing and made-ups are highly demanded in the export market of USA, UK, Germany, Italy and Australia. Today, about 95 per cent of the world's hand woven fabric comes from India (Government of India, 2012-13). The major importing countries of Indian handloom goods are United States, Germany, United Kingdom, France and Australia. Some of the leading international players that import Indian handloom products include IKEA, WalMart, Target Corporation, Habitat and Town and Country Linen.

In the changed globalised economic scenario, it is strongly felt that export has become immensely beneficial for survival and growth of Indian handloom. Government of India, too, has laid emphasis on promotion of export activity under the New Textile Policy. Mira Seth Committee has suggested in its report that the thrust on export of handloom may turn it into an attractive and more remunerative industry. The global developments and economic reforms that swept the world have drastically changed the global business environment. If the handloom industry is to take up exporting as its major thrust area an export culture needs to be developed among all the channel members of the supply chain such as weavers, dyers, printers and designers etc. These channel members must, not only understand but also realise the importance of the essentials of the activities involved in exporting. Export of handloom demands the reorientation of activities for survival, growth and development and the industry. For this purpose, handloom exporters have to shift their focus to the newer marketing issues for making handloom more competitive at the floor of global market.

\subsection{Objectives and significance of the study}

Various issues have been identified and discussed by different authors. The literature suggests that the marketability of handloom products need to be strengthened, 
besides governmental support and other measures. For increasing the marketability of handloom products in global market, a marketing strategy is to be developed taking into account various product mix dimensions. In absence of any empirical study focused on developing such strategy, an empirical investigation is required to study the causal relationship of different marketing mix variables. It is, therefore, the scope of this study to investigate into the construct of the different variables in the export marketing of the handloom products.

Thus, the main objective of the study is to understand the export marketing processes of Indian handloom industry and to bring out strategic suggestions for a better market performance of this industry. This was complimented with specific objectives to identify the important elements in the export of handlooms; to find their relationship with one another and to suggest to handloom exporters the appropriate designs of their strategy for improving export performance. The objective of the study also includes giving suggestions to the government to take policy initiatives.

The outcomes of this study will give directions to the practitioners of handloom industry viz. exporters and manufacturers to focus their attention on the particular issues in the marketing of their products, besides offering suggestions for government to improve the performance of the industry. The marketing strategy guided by the outcomes of this study will give the base for positioning of the handloom products, and improving their marketability in global market. When the export of handloom goods increases, handloom industry becomes an attractive and profitable industry, and handloom weavers get more work and remain associated with handloom activities only. Therefore, the threat of unemployment of handloom weavers can be minimized.

A healthy growth and development of handloom industry will gift the weavers with rewarding engagements on one hand and will prevent the social evils caused by unemployment of a large population on the other, besides the economic gains through export of handloom products. The significance of this study lies ultimately for the cause of society through employment of handloom weaver by improving marketability of handloom products.

The flow of the remaining article is as follows. After having a brief review of the sector in the introduction part, the following section briefly reviews the policies framed and institutions created by the Government of India. Section 3 evaluates the export performance of handloom sector. Section 4 reviews the existing literature; Section 5 develops the framework for analysing the factors that influence handloom export and section 6 interprets the empirical results. The last section summarises the main findings and gives directions for further research. 


\subsection{Government Policies and Institutions}

Government of India, after the independence, realizing the importance of this decentralized rural based industry, has always been supportive through several policy initiatives and programs. The interventions in the earlier plans were through cooperative societies or state agencies. Various schemes were initiated from time to time for the socio-economic welfare of the weavers and improvement in the performance of the industry. Some of the schemes continued for long and some were withdrawn or modified. After globalisation the emphasis of the government was on making the industry more competitive and self-sustaining. Hence, all the programs are designed around the competitiveness and self-sustainability. Here a general assessment is made on the policies directly or indirectly related to exporting.

\subsection{Policy Initiatives}

The nature of schemes introduced by the Government of India from time to time varied from marketing to welfare of weavers, support in the price of inputs and reservation of items for handloom sector and institutional support. Schemes such as Health Insurance Scheme, Mahatma Gandhi Bunkar Bima Yojana, Mill Gate Price Scheme, Mega Handloom Clusters Scheme, Implementation of Reservation of Handloom Articles, Integrated Handloom Development Scheme and Diversified Handloom Development Scheme were introduced. For marketing support various schemes were introduced for domestic and export promotion too. These schemes were reorganized in the $12^{\text {th }}$ Plan into Comprehensive Handloom Development Scheme (CHDS) with an objective of making it competitive. CHDS has been formulated by merging the components of Integrated Handloom Development Scheme (IHDS), Marketing \& Export Promotion Scheme (MEPS), and Diversified Handloom Development Scheme (DHDS), implemented during the 11th Plan, were aimed at development of handloom through cluster approach. The sub-components of the CHDS are cluster development, handloom marketing assistance, development and strengthening of the handloom institutions, handloom census, implementing innovative ideas and publicity, advertisement, monitoring, training and evaluation of the schemes.

The erstwhile Marketing and Export Promotion Scheme has been merged into CHDS and Handloom Marketing Assistance, as one of the components of Comprehensive Handloom Development Scheme has been introduced during the 12th Plan. The scheme follows need based approach for integrated and holistic development of handlooms and welfare of handloom weavers. The major shift from the earlier schemes is making handloom sector competitive. Merchandising and marketing has been 
recognized as being central to the growth and development of the handloom sector in India. The main objective of the handloom marketing assistance is to provide marketing platform to the weavers and handloom organisations to sell their products directly to the consumers. Different components of the marketing assistance are organising marketing events or expos, handloom mark, geographical indications, development of web portal, publicity, awareness, promotion, setting-up of handloom marketing complex, and design and quality intervention etc. A component of the handloom marketing assistance is export promotion. Realising the fact that the export of handlooms plays a pivotal role in the Indian economy and accounts for a major foreign exchange earner for the country the government paid attention to export promotion. After globalization, due to free global trade the policy initiatives are focused on enhancing competitiveness of the exporters. Only those exporters which are able to provide quality products at competitive price will be able to survive. The objective of the handloom export promotion is to assist the handloom cooperative societies, corporations and handloom exporters in brand promotion and to participate in international events; buyer-seller meets etc. and to make available the latest designs, trends, color forecasts etc. Under this component, assistance is given for export projects, participation in international fairs and exhibitions, and setting up of garment units, design studios. Under the scheme Government of India provides assistance to the level of 80 per cent of the project cost. During the year 201213 various handloom agencies and exporters participated in 09 international fairs/exhibitions. During the year 2013-14 participation in 19 international exhibitions and 3 buyers sellers meet have been approved.

\subsection{Institutional Support}

For protection, development and growth of handloom industry several institutions were created with the objective of augmenting technical and marketing support. Realising the significant role of export the Government of India created institutions for promoting export of handloom and also concerning direct export. The most vital institution for the promotion of handloom is the Handloom Export Promotion Council (HEPC).

Handloom Export Promotion Council: This Council was set up in 1965 by the Ministry of Textiles, Government of India with the primary objective of providing all support and guidance to Indian handloom exporters and international buyers for trade promotion, international marketing and promoting exports of all kinds of handloom products. Presently there are about 1300 members. The head office of HEPC is at Chennai, while regional office is at New Delhi. The specific objectives of the Council include dissemination of trade information to the exporters, publicity of Indian 
handloom products abroad and to liaison with the Government of India on all relevant procedural and policy matters. It also provides design inputs, facilitates product diversification and provides impetus to modernisation. It organises business missions, buyer seller meets and trade fairs abroad. The council not only provides consultancy to exporters but also liaisons with import promotion and commercial agencies abroad for the benefit of handloom exporters and helps in dealing with trade complaints pertaining to handloom exports. In the year 2013-14 HEPC has participated in 14 International fairs held abroad. The council has so far organised four editions of India International Handwoven Fair (IIHF). In the $4^{\text {th }}$ IIHF 2014 about 150 foreign buyers were invited, where nearly 200 Indian exporters showcased their products. As an important activity, the council organises awareness seminars across the handloom production centres from time to time. Six such seminars were organised during 2013-14.

In addition to HEPC several institutions were started to provide technical support. A chain of twenty five Weavers Service Centres (WSCs) across the country play a crucial role in skill up-gradation and capacity building to improve productivity through transfer of design inputs, skill and technology. To produce professionally qualified and trained manpower to the handloom sector and undertake experimental and research programmes on all aspects of the handloom industry five Indian Institutes of Handloom Technology were started. Another institution namely National Centre for Textile Designs (NCTD) was set up in 2001 to promote traditional and contemporary designs to make handloom sector more responsive to the rapidly changing market demand and to give weavers and designers greater exposure and access to national and international markets. The National Handicrafts and Handlooms Museum also known as Crafts Museum, New Delhi aims at increasing public awareness about India's ancient traditions of handicrafts and handlooms, providing an interactive forum for craftsperson, designers, exporters, scholars and the public and help craftsperson find a platform for marketing without middlemen and serve as a resource centre for Indian handicraft and handloom traditions. National Handloom Development Corporation (NHDC), set up in 1983, helps in ensuring the supply of different varieties of yarn and dyestuff to the handloom exporters at the right price.

A couple of institutions were created to directly export a range of handloom products from diverse parts of the country. The Handicrafts \& Handlooms Exports Corporation (HHEC) was established by the Ministry of Textiles, Government of India in the year 1958 with the twin objective of export promotion and trade development of handicraft and handloom products. It is successfully engaged in export of handloom and handicraft products. 
All India Society, a national level handloom cooperative society is engaged in marketing of handloom product within the country and abroad. It has its export houses at NOIDA, Karur and Chennai. The Society has also showroom at Mauritius for marketing of Indian handloom goods. Society is profitably undertaking exports of handloom merchandise.

\subsection{Export Performance of Indian Handloom}

\subsection{Product category-wise exports}

Data on export of handloom goods for the years from 2009-10 to 2013-14 is obtained from the website of Development Commissioner (Handloom) given in Indian Rupees (Rs.). Table 1 reveals that the total export of handloom increased from Rs. 12528.9 million in 2009-10 to Rs. 15749.5 million in 2010-11showing an increase of above 25 per cent, which further grew to Rs. 26239.7 million in 2011-12 exhibiting a rise of more than 66 per cent over the previous year. It further grew to Rs. 28119.7 million in 2012-13 displaying an increase of about 7 per cent. It declined to Rs. 22331.1 million in 2013-14 by suffering a decrease of about 20 per cent. Overall the rate of growth accounts to about 20 per cent in this period.

Table 1: Product category-wise export of handloom products

\begin{tabular}{|l|c|c|c|c|c|}
\hline \multirow{2}{*}{$\begin{array}{l}\text { Product } \\
\text { Category }\end{array}$} & \multicolumn{5}{|c|}{ Export (in million rupees) } \\
\cline { 2 - 6 } Fabric & $\mathbf{2 0 0 9 - 1 0}$ & $\mathbf{2 0 1 0}-\mathbf{1 1}$ & $\mathbf{2 0 1 1 - 1 2}$ & $\mathbf{2 0 1 2 - 1 3}$ & $\mathbf{2 0 1 3 - 1 4}$ \\
\hline \multirow{2}{*}{ Made-ups } & 652.1 & 714.9 & 785.9 & 520.5 & 596.4 \\
& $(5.21)$ & $(4.54)$ & $(3.00)$ & $(1.85)$ & $(2.67)$ \\
\hline Floor & 11285.9 & 13532.5 & 21325.1 & 20667.7 & 11581.5 \\
Covering & $(90.08)$ & $(85.92)$ & $(81.27)$ & $(73.50)$ & $(51.86)$ \\
\hline Clothing & $(4.64)$ & 1470.2 & 3766.1 & 6191.4 & 9486 \\
Accessories & 8.6 & $3.34)$ & $(14.35)$ & $(22.02)$ & $(42.48)$ \\
\hline \multirow{2}{*}{ Total } & $(0.07)$ & $(0.20)$ & $(1.38)$ & $(2.63)$ & $(2.99)$ \\
& 12528.1 & $\mathbf{1 5 7 4 9 . 6}$ & $\mathbf{2 6 2 3 9 . 7}$ & $\mathbf{2 8 1 1 9 . 7}$ & $\mathbf{2 2 3 3 1 . 1}$ \\
\hline
\end{tabular}

Figures in parenthesis show percentage of the product category in that year

Source: http://handlooms.nic.in/Writereaddata/1296.pdf

The analysis of category-wise export also reveals that made-ups is the most exported category of handloom products, which comprises of bed linen, table linen, and 
30 | FOCUS: Journal of International Business, Vol. 2, Issue 1

cushion cover (Figures 1 and 2). The percentage of made-ups in the total export, though, declined in percentage terms from 90 per cent to 85 per cent, but increased in rupee terms from Rs. 11285.9 million in 2009-10 to Rs.13532.5 million in 2010-11 showing an increase of 20 per cent, which further improved to Rs. 21325.1 million in 2011-12 registering a rise of more than 57 per cent.

Figure 1: Product category-wise export volume

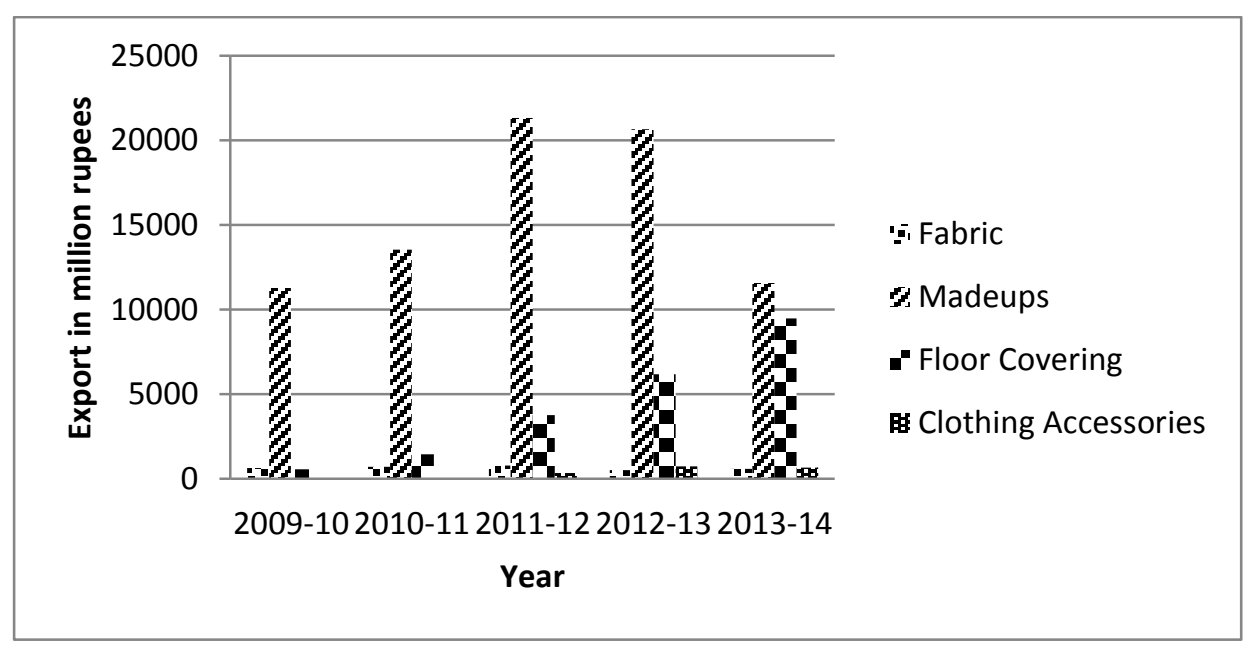

Figure 2: Product category-wise share in handloom export

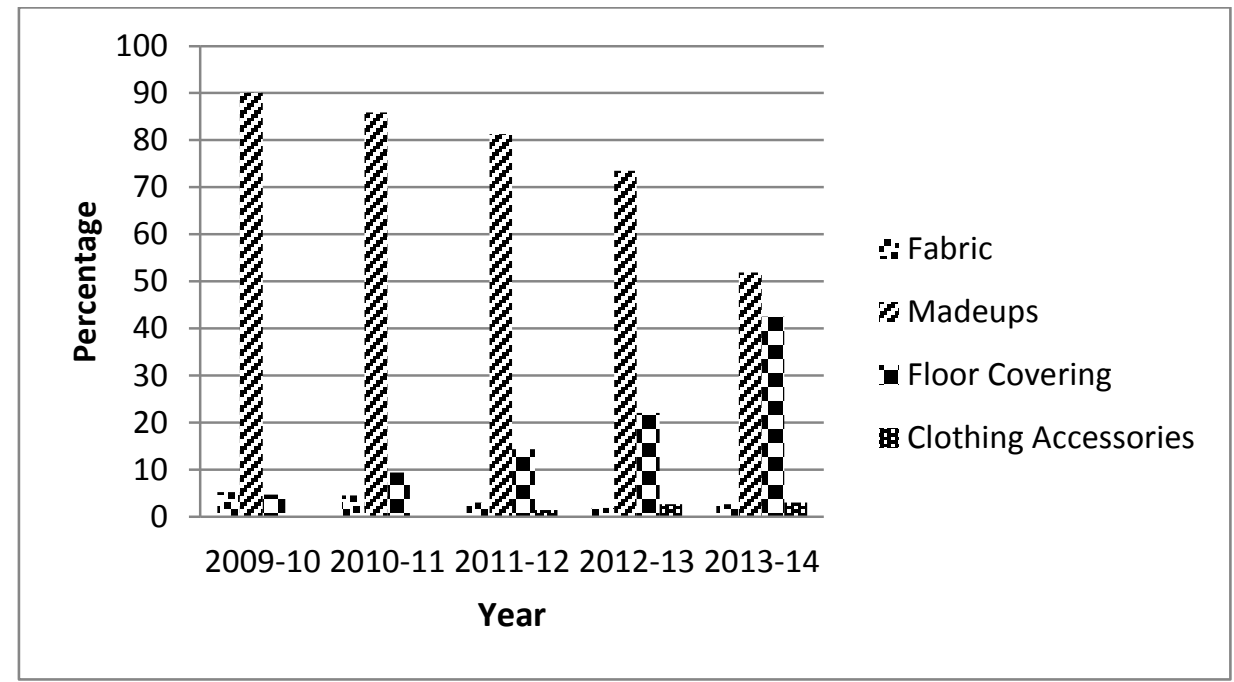


It further increased to Rs. 20667.7 million, in 2012-13 showing a marginal drop of about 3 per cent. A sharp decline is visible during 2013-14 when the total made-ups export fell to Rs. 11581.5 million and its share in handloom came down to about 52 per cent from 73.5 per cent. Floor covering comprising of durries, floor mats and door mats etc., is the next category in terms of its share in the handloom export. Remarkably it is showing an increasing trend. Its export share to the total export has increased from about 5 per cent in 2009-10 to about t 10 per cent in 2010-11 to more than 14 per cent in 21112 and 22 per cent in 2012-13. In absolute rupee terms the export of floor coverings rose from Rs. 581.5 million in 2009-10 to Rs. 1470.2 million in 2010-11 showing a growth of 153 per cent and to Rs. 3766.1 million in 2011-12 exhibiting a surge of about 156 per cent. The export of floor coverings increased to Rs. 6191.4 million in 2012-13 shows a growth of about 64 per cent over the previous year. The performance of this category improved substantially in rupee terms as well as in percentage in 2013-14. Total madeups export increased to Rs. 9486.1 million registering a growth of 53 per cent. Its share increased from 22 per cent in 2012-13 to 42 per cent of the total handloom export in 2013-14.

Another category which is exhibiting impressive increase is clothing accessories, which has increased from negligible 0.07 per cent in 2009-10 to meager 0.20 per cent in 2010-11 to 2.63 per cent in 2012-13. The export of clothing accessories increased from mere Rs. 8.6 million in $2009-10$ to Rs. 32 million in 2010-11 registering a growth of 272 per cent. It increased to Rs. 362.6 million in 2011-12 registering a sharp rise of 1031 per cent. Further, in in the year 2012-13 it touched Rs. 740.1 million showing a surge of about 104 per cent though showed a decline of 10 per cent in the next year and reached to Rs. 667.1 million. The performance of fabric export is dismal, which is declining from 5.21 per cent in $2009-10$ to 4.54 per cent in $2010-11$ to 3 per cent in 2011-12 to 1.85 per cent in 2012-13. In absolute rupee terms though fabric export increased from Rs. 652.1 million in 2009-10 to Rs. 714.9 million in $2010-11$ and to Rs. 785.9 million in 2011-12 exhibiting an annual rise of 9 to 10 per cent. Fabric export figures declined sharply also to Rs. 520.4 million in 2012-13 displaying a drop of more than 33 per cent. From the above enquiry it can be concluded that mere fabric is losing its attraction, but value-added products such as floor coverings, clothing accessories and made-ups are getting more appreciation and the future of handloom exports lies in the conversion of fabric into such products which are ready for use.

\subsection{Continent-wise exports}

Data about the continent-wise break-up was available with website of Handloom Export Promotion Council (HEPC) for three years from 2010-11 to 2012-13. On its 
analysis it was found that about half of the handloom produce are exported to America (Table 2). The European Union is the next highest importer with a share of about onethird. Therefore, about 75 per cent of the handloom goods are exported to America and European Union put together. The export to Asian countries is in the range of about 10 per cent.

Table 2: Continent-wise export of handloom produce

\begin{tabular}{|l|c|c|c|}
\hline \multicolumn{1}{|c|}{ Continents } & $\mathbf{2 0 1 0}-\mathbf{- 1 1}$ & $\mathbf{2 0 1 1 - 1 2}$ & $\mathbf{2 0 1 2 - 1 3}$ \\
\hline Africa & $317.7(2.02)$ & $763.9(2.91)$ & $1325.0(4.71)$ \\
\hline America & $7445.5(47.27)$ & $12724.2(48.49)$ & $13951.2(49.61)$ \\
\hline $\begin{array}{l}\text { Other American } \\
\text { Countries }\end{array}$ & $536.5(3.41)$ & $851.7(3.25)$ & $1233.1(4.39)$ \\
\hline Asia & $1575.2(10.00)$ & $2335.4(8.90)$ & $3003.0(10.68)$ \\
\hline European Union & $5084.8(32.28)$ & $8202.0(31.26)$ & $6996.9(24.88)$ \\
\hline Europe Others & $180.5(1.15)$ & $343.5(1.31)$ & $372.3(1.32)$ \\
\hline Oceania & $579.8(3.68)$ & $1019.1(3.88)$ & $1236.4(4.40)$ \\
\hline Others & $29.6(0.19)$ & $0(0.00)$ & $1.8(0.01)$ \\
\hline Total & $\mathbf{1 5 7 4 9 . 6 ( 1 0 0 )}$ & $\mathbf{2 6 2 3 9 . 8 ( 1 0 0 )}$ & $\mathbf{2 8 1 1 9 . 7 ( 1 0 0 )}$ \\
\hline
\end{tabular}

Figures in parenthesis show percentage of the product category in that year Source: http://www.hepcindia.com/government.php

Country-wise export is highest to USA followed by UK, Germany and Australia (www.hepcindia.com). Export figures for African countries show some signs of improvement as it increased from 2.02 per cent in 2010-11 to 4.71 per cent in 2012-13. But, it is noteworthy that the pattern of export to different continents is the same in all the three years of observation, though the figure for EU has marginally declined in 201213 and the export to African countries is on a rise (Figures 3 and 4). It is also evident that the export of Indian handloom is heavily dependent on USA and Europe. Development of alternative markets may prove to be useful. The exporters may explore the possibility of exporting to those continents and countries where the export is presently less.

\subsection{Review of Literature}

Despite the fact that global competition has increased, immense opportunities exist in handloom export. Several studies, highlighting the potential of handloom export and need to tap it through concentrating on different aspects, are available. Pillai (1986) highlight the need of and suggested efforts to increase the export of handloom goods. Bhagirathi and Sengupta (2003) suggest that even if export is not the purpose of 
production, craft still have to be export worthy to survive. Venkatachalam (1992) emphasised the need of coordination between producers and merchant exporters. The author also tries to impress upon the importance of quality at every level in the export operation.

Figure 3: Continent-wise export of handloom products

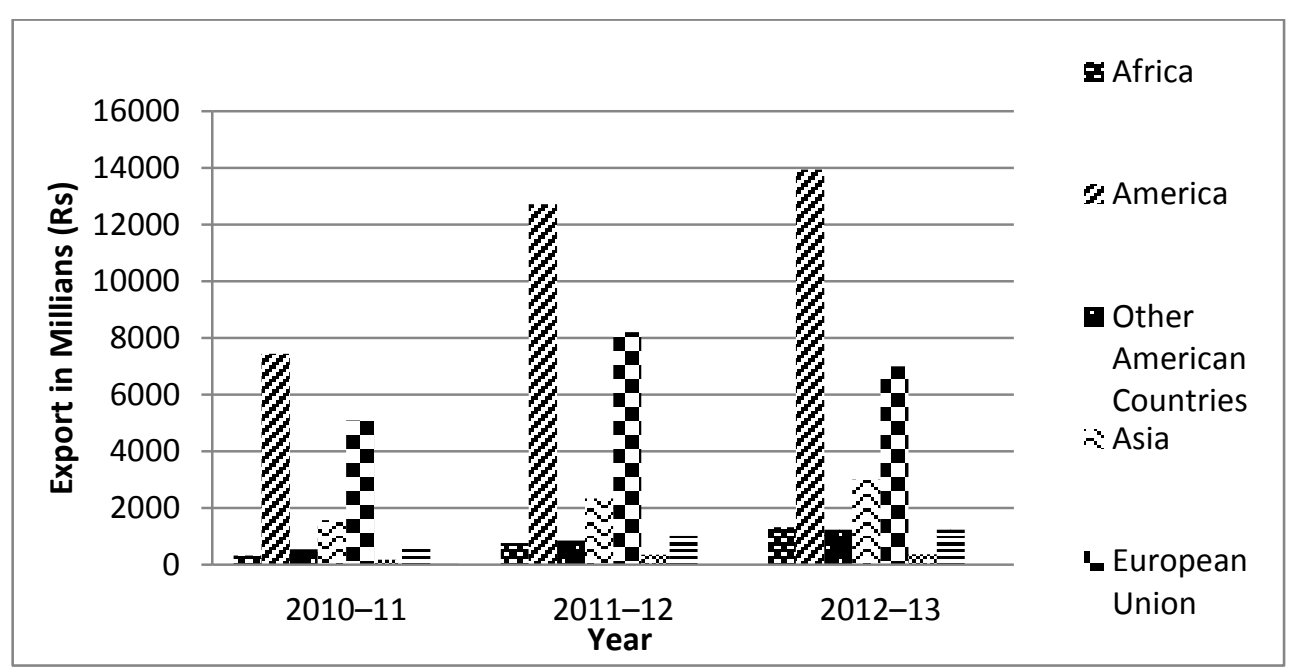

Figure 4: Continent-wise share in handloom export

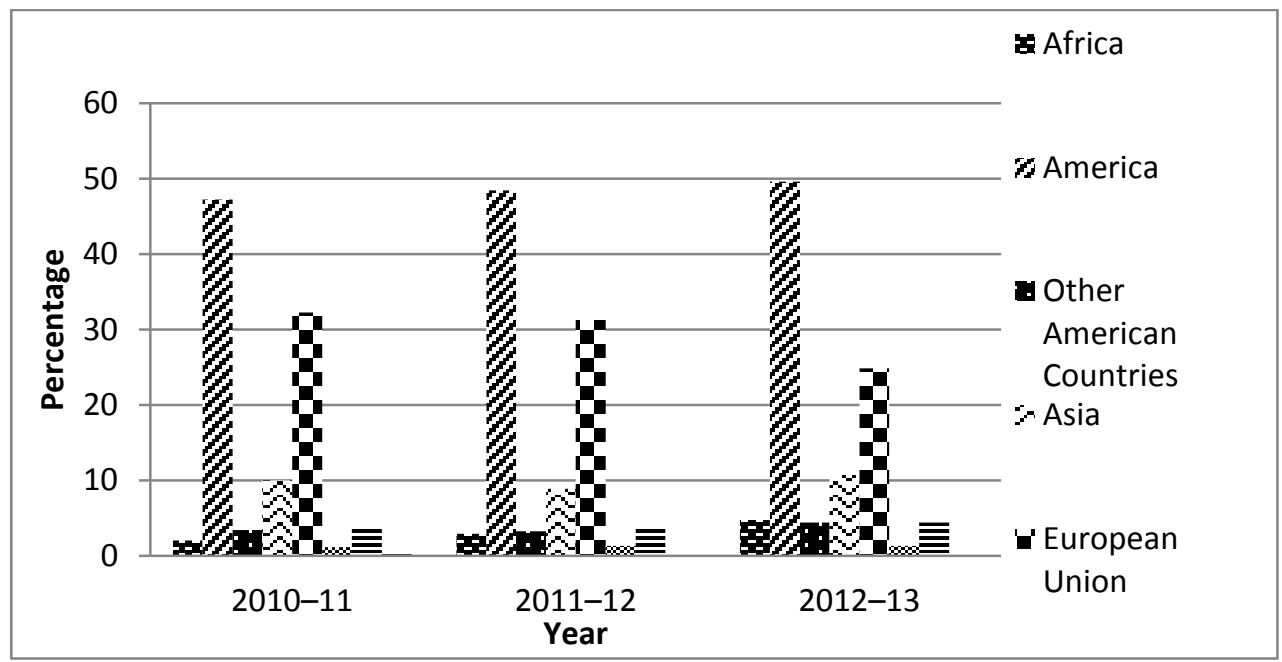


Gulati (1998) emphasise on developing eco-friendly products for export market. Gurumurthy and Rengachari (2002) feel that to tap the opportunities of handloom products in the global market, the Handloom Export Promotion Council (HEPC) has to ascertain and predict the demand in the overseas market. Thillinayagan and Muruganandan (2002) come out with a range of suggestions for the export of handlooms. The suggestions include creating new markets, entering into new and more products in made-ups, use of eco-friendly colors, more aggressive promotion and strengthening of governmental support system. Aulakh Preet et. al. (2002), while analysing the export strategies find out that cost leadership strategies is more pronounced when the target market focus is on developed countries; and differentiation strategy leads to improved performance if the market foucs is on developing countries. The authors conclude that the standardized marketing programs tend to result in lower performance. Vishwanath (2004) feel that for the success of export business, buyers confidence be built not just on good products but also on showing seriousness about making contract. Mehta (2004) asserts that the export market has grown for Indian crafts and textiles; and there exist the potential for further growth.

In the existing literature, various marketing related problems and suggestion on market, marketing system and marketing processes are discussed by academicians, industry experts and freelance writers came to the surface. Though very little empirical work has been done, the works lack broad orientation and comprehensiveness. Many of the literature are conceptual in nature. In different studies various marketing aspects are discussed by different authors. Karunakaran and Karthikeyan (2002) focus on understanding consumer need, Thakur (1995) emphasise on product innovation and development; Rajan (2004) discusses the importance of designing. Many other issues are highlighted in different literature such as fashion orientation (Rao and Subramanyam, 1995), quality (Venkatachalam, 1995; Thakur, 1995; Kasturi, 2006), brand image (Leible and Roy, 2003), publicity support (Gulati, 1998), promotional efforts (Rao, 1998), inshop convenience and visual appeal (Modak, 2006), pricing (Housego, 2003) and adopting a market approach (Thakur, 1995; Gurumurthy and Rengachari, 2002). A number of studies are available on the issues related to the export marketing of handloom products. Thillinayagan and Muruganandam (2002) discuss various issues like creating new market, entering into new products, aggressive promotion and governmental supports. Venkatacham (1995) emphasise on quality issues and Vishwanath (2004) discuss the importance of winning buyers confidence. The above literature has helped in forming the idea about the basic problems of the handloom sector as a whole and marketing of handloom products in domestic market as well as exports. 


\subsection{Issues in Handloom Exports}

There are a number of issues, which require the attention of exporters, important being ability to deliver within agreed deadline, good communication, honesty and ability to serve individual needs. In addition to the above, other important aspects are infrastructure, market information, production and the regulatory framework (Toften and Rustad, 2005). The more important facets pertinent for the handloom export are discussed in below paragraphs.

Market Information: A successful marketer knows substantially about the surroundings, consumers and their behaviors to cater to their needs in a better way. In the international business too, awareness about the geographic, economic and demographic environment of the foreign country along with the information about legal conditions; and the global business environment are useful for smooth running of the businesses. Export market knowledge may provide a deeper understanding of the relationship between use of export market information and export performance (Toften and Olsen, 2003). With the increasing export activity, information about the international environment becomes critical (Richey and Myers, 2001). Specific marketing related detailed information such as consumer preference, economics, trend, culture and regulatory framework (Toften and Rustad 2005). To enable the handloom products meet the requirements of the respective market, the handloom exporters need the information about the importing countries with regard to their economic, geographic and demographic characteristics. Kumar (1983) stressed upon the need of market intelligence for the success of handloom exporters. They must also be aware of the import regulation of the countries to which they export. They need to know about the market characteristics of the importing countries, the marketing process there, and the marketing system. Enriched with this information, the demand of handloom products can be created globally and the offerings can be designed suitably.

Product differentiation: Export markets are considered to be having entry barriers. Firms with greater marketing efforts in terms of product innovation, product differentiation promotional measures and building brand image do better than the firms with lower marketing efforts (Pradhan, Zohair and Alagavadi, 2013). Marketing skills are often considered to be relatively scarce resources that hinder their manufacturing exports for the firms in developing countries (de la Torre, 1971). Many firms spend lot on sales promotion efforts to differentiate their products from their competitors through building brand image (Pradhan, 2008). New varieties must be developed to meet the competition from countries like Bangladesh and Pakistan (Thillinayagan and Muruganandan). 
Delivery: In export business the goods have to be delivered in time. Delivery within agteed deadline is important for success in export (Toften and Rustad, 2005). A late delivery of goods usually attracts penalty in the form of bearing the cost of air-freight and sometimes compensation depending upon the time by which the delivery is delayed. Due to the penalty the exporters many incur moderate to huge loss. The handloom exporters and all the channel members of the entire supply chain must appreciate the importance of prompt delivery and ominous consequences of late delivery; and therefore put serious efforts to complete the export order in time. For this a complete export culture has to be build, and all the channel members in handloom production should have a proper understanding of export business. The successful exporters around the globe recognize the fact. One of the reasons of success of China in the global trade is the prompt delivery.

Pricing: The export market is highly price conscious and pricing is an important and crucial decision in the negotiation of export orders. Due to mounting competition the vendors from different countries are competing at the global market place for price. Crick and Katsikeas (1995) found a significant role of pricing on the export performance. But the products with exclusive features still have the ability to fetch a better price. The Indian handloom products, on account of the exclusiveness of design and other product features have their own reputation, and therefore, can be priced at relatively higher level. But in this exercise the worth of the product must be justified and prices should be quoted differently for different buyers of different markets.

Communication: In export business the importance of responsiveness in terms of rapid feedback and good flow of communication is paramount (Toften and Rustad, 2003). The handloom exporters have to pay due attention to provide the right kind of information to their buyers whenever they are needed. On many occasions the proper communication saves the exporters from some unpleasant situations to arise. In export business, very often, a situation may arise which is not acceptable to the buyers in ordinary circumstances, but the buyer can be convinced to accept it through proper and timely communication.

Market exploration: Though export market exploration improves export performance under high levels of export market turbulence, balancing export market exploitation with export market exploration enhances export performance (Lisboa et. al., 2013). At present a third of the handloom exports are being made to USA and Europe each, being the highest consumers of the Indian handloom products. More and more handloom exporters from India try to export their products to these countries only. Due to higher number of vendor trying to sell to the same market, the situation is becoming more competitive, which results in market saturation, decrease in price level and ultimately 
decrease in the profit. Now, more exploration should be done to find new markets globally. In this way, the demand of the handloom products can be created and the consumption can be increased by finding the new segment of the consumers. Therefore, market exploration and market expansion should be placed at higher on priority of the Indian handloom exporters.

Quality: Quality of the goods being exported is of paramount importance (Venkatachalam). It is the deciding factor in sustaining export as the buyers are quality conscious with regard to dyeing, colour fastness and rubbing fastness etc. (Iyer, 2000). The exporters must ensure the improved quality control system in place (Christopher and Nagarajan, 2002). Use of raw material of correct quality and adherence to the standards specified by the buyers must be taken seriously by the exporters.

Government assistance: The government has been assisting the handloom sector through a variety of development, welfare and marketing schemes. These measures such as duty-drawback, export credit, export insurance, tax holiday on export income are likely to play a positive role in promoting export activities (Pradhan, Zohair and Alagavadi, 2013; Pradhan and Sahu, 2008; Roy, 1993; Fitzgerald and Monson, 1989). The schemes for the handloom exporters are aimed at helping them through monetary incentives, research and development and market information etc. in addition to the marketing support. Government organizes the buyer-seller meets, exhibitions and fairs and publicity campaign, through its agencies like Handloom Export Promotion Council. This support mechanism is crucial and useful to the exporters and desired by them. Government must ensure that the schemes are properly implemented to bring the desired result for the nation.

Indian handloom products are still preferred and admired in the global market for its artistry and several unique features. Having growth potential in the global market, handloom deserves to be promoted in India and the Indian handloom exporters need to be motivated and encouraged so that they put their maximum efforts to promote it. In addition to the several support measures from the government and governmental agencies for promotion of handloom exports the exporters have to put their efforts in the direction of gathering useful and relevant market information, proper communication, product innovation and product development. Appropriate pricing, adhering to the quality norms, and honoring the delivery schedule are also some of the crucial areas on which the exporters have to concentrate. In this manner the demand of Indian handloom in the global market can be created, which may benefit the industry at large and earn more foreign exchange for the country. 


\subsection{Research Methodology}

This research can be categorised as exploratory as well as descriptive. It is an exploratory research because it tries to explore the research issue, define the problem precisely and isolate key variables in the marketing of handloom in export market. This study is a descriptive study too because it tries to describe the phenomenon or characteristics associated with the subject (Cooper and Schindler, 2006) of marketing of handloom products and to discover association (Cooper and Schindler, 2006) among different variables for formulating marketing strategy.

\subsection{Exploratory Investigation}

Extensive survey of related literature was done on handloom industry itself, its nature, various problems of handloom industry and marketing of handloom products; through books, articles and papers published in various journals and periodicals. Many conferences were attended on the theme of handloom. Industry information were gathered through press releases of the government and the websites of various government agencies such as office of the Development Commissioner (Handloom), Ministry of Textiles, Textile Committee, Planning Commission and Handloom Export Promotion Council etc. Information was gathered through other non-government websites also. Detailed survey of literature is separately given above. Initially several visits were made to the areas dominated by the weavers community in Varanasi to look into the variety of the problems of handloom sector. Many weavers' representatives, experts and exporters were also contacted. Several visits were made to the Indian Institute of Handloom Technology, Varanasi to meet the faculty members there, and the knowledgeable persons of the areas of handloom. An exploratory qualitative investigation was undertaken to better understand the key dimensions of marketing of textile and handloom. For this purpose, personal in-depth interviews, comprising of open ended questions with the consumers, retailers, manufacturers and exporters of handloom were conducted. These investigations were conducted at Varanasi, Chennai, Karur and Salem. Several respondents from each category were selected randomly and interviewed. The in-depth interviews were focused on the problems and priorities of handloom exporters.

Data Source: The basic information about the handloom industry was gathered through many different secondary sources. The important sources of secondary data with respect to handloom sector are the Economic Survey Reports of various years published by the Government of India, various document related with different Five Year Plans, published by the Planning Commission, Government of India, data published by Ministry of 
Textiles, Government of India, data published by Directorate General of Commercial Intelligence and Statistics, data published by Handloom Export Promotion Council, various reports published by state and union governments. These secondary sources provide many useful data about the various aspects of employment, production, export and growth of handloom sector.

\subsection{Primary Investigation}

It is always better to use secondary data for further analysis because of convenience of data collection, time saving, economy and reliability. But researcher must be very careful in using secondary data because it is just possible that the secondary data may not be suitable or may be inadequate in the context of the problem which the researcher wants to study (Kothari, 2004). As no appropriate secondary data is available in line with the objectives of this research, to find the key factors in marketing of handloom products, it was, therefore, decided to collect data from suitable primary source.

For formulating the marketing strategy for global market, the useful information can be gathered through buyers or importers. As getting information from the buyers or importers has got certain limitations such as their overseas locations, alternatively the other segment, which can give useful information, is the handloom exporter. The perception of the handloom exporters about the environmental factors, and the direction of their efforts in the export of handloom products can be known from them. The support measures of the government for promoting handloom export also play an important role. All these information can be obtained from the exporters, which can help in identifying the key elements in the export marketing of handloom.

Design of Survey Instrument: To survey the handloom exporters a questionnaire was designed and developed from the inferences obtained through the review of the subject and from the exploratory studies. The questionnaire consists of various items representing different variables on different aspects of handloom export marketing measuring on a five-point Likert scale ranging from "1: Strongly disagree" to "5: Strongly agree". Some items were evaluated on scale ranging from "1: Not important at all" to "5: Extremely important". The structured questionnaire has items carefully worded, properly selected and logically sequenced. Items affecting the sentiments of the respondents were avoided. Many items seeking categorical information were also included. Questionnaire was neatly typed on paper of good quality to ensure proper presentation.

Pre-testing of the Instrument: Questionnaire should be administered after adequate pretesting on a small sample of respondents for the purpose of improving the 
questionnaire by identifying and eliminating potential problem (Malhotra, 2005). In this research work the process of pretesting was completed in two stages. In the first stage the questionnaire was tested for the content validity with the help of academicians and the experts. In the second stage the questionnaires was tested through pilot study with 10-12 respondents of handloom exporters. As a result of pretesting and pilot survey several items were removed from the questionnaire to bring the number of items/questions to the optimum level from the view point of the respondents' ease. A few questions/items were added afresh in accordance with the research objective. Further, the wordings and sequence of many items were changed to get the desired sense of the questions and ensure smooth flow of the questionnaire so that the respondents may find the questionnaire interesting. Pretesting and pilot survey were found to be very useful in giving the final shape to the questionnaires.

Samples: In this research project, as the size of the target population for the study is relatively larger, appropriate sample is selected for survey. For this study the target populations are selected and defined as handloom exporters - the exporters dealing in handloom and registered with Handloom Export Promotion Council (HEPC). The target population, sample size and locations of the survey are selected as discussed under:

The directory of the members of HEPC with the list of 963 members from all over India was taken as sample frame for population of handloom exporters. In order to know the exporters' view point on different variables of handloom export, it was decided to cover south India as well as north India. Tamil Nadu having the high concentration of handloom exporters with 455 member exporters was chosen to represent south India. In north India, on the other hand, Delhi is the major hub of exporters. These exporters deal with the handloom products produced in the neighbouring production centres of Uttar Pradesh, Haryana and Rajasthan. The nature of product and behaviour of the exporters of Uttar Pradesh and Haryana are similar to that of Delhi. Therefore, Haryana and Uttar Pradesh were also selected for survey along with Delhi to represent north India. The total number of member exporters from these three states is 314 . It was decided to send the questionnaires to 25 per cent of the target population. Therefore, following systematic sampling every $4^{\text {th }}$ name was selected from the HEPC directory for sending the questionnaire.

Data Collection/Field Work: A questionnaires for handloom exporters was finally ready after pre-testing and pilot survey to be administered for seeking responses from identified samples of target populations. In the handloom exporters category every $4^{\text {th }}$ name from HEPCs Exporters Directory was selected and the questionnaires were mailed. The detail of the questionnaires mailed and the responses received are given in the Table 3. A stamped self-addressed envelope was put inside along with the questionnaire. Very 
few of them (about 10) were returned undelivered as the addressee was not found at the address. Some of the completed questionnaires were received by return mail. Reminders were made to the others through phone call when the completed questionnaires did not reach. A lot of questionnaires were collected personally by the researcher and the volunteers at Karur, Chennai, Delhi, Panipat and Varanasi. Total number of 119 usable responses were received (75 from the south and 44 from the north India), which were used for further analysis. In the space provided for the free comments, many respondents came out with their own ideas. Many respondents liked the subject, enjoyed replying the questions and even acknowledge with their complimentary comments.

Table 3: Exporters Sample Details

\begin{tabular}{|l|c|c|c|}
\hline \multicolumn{1}{|c|}{ Region } & $\begin{array}{c}\text { Total Number } \\
\text { of Members }\end{array}$ & $\begin{array}{c}\text { Number of } \\
\text { Questionnaires Mailed }\end{array}$ & $\begin{array}{c}\text { Number of Usable } \\
\text { Responses Received }\end{array}$ \\
\hline South (Tamil Nadu) & 455 & 114 & 75 \\
\hline $\begin{array}{l}\text { North (Delhi, } \\
\text { Haryana and U.P.) }\end{array}$ & 314 & 78 & 44 \\
\hline Total & 769 & 192 & 119 \\
\hline
\end{tabular}

Data Analysis: The collected data, after checking and editing was entered into the SPSS 12.0 (Special Package for Social Science) for analysis. Different statistical tools were used depending upon their suitability and requirement for the analysis. The basic information was cross-tabulated for having a broad understanding of the nature of the sample. Further, to test the significance of each variable in isolation, one-sample t-test was applied to each item of the questionnaire. In order to formulate the marketing strategy, the task was to eliminate the weak variables, picking the minimum number of the predictor variable and measuring the proportionate contributions made by each significant variable to the explanation of performance differential, a stepwise multiple regression analysis of the data was carried out (Clawson, 1974).. Cronbach's alpha was calculated to measure the internal consistency of the instrument that is, the degree to which instrument items are homogeneous and reflect the same underlying construct (Cooper \& Schindler, 2006).

\subsection{Results and Discussion}

For developing a strategy for the export of handloom a number of variables were identified on studying the existing literature and interacting with the handloom exporters. 
The variables were identified with respect to the exporters' action, perceptions, intentions and expectations. Some variables are identified on the basis of the exporters' strengths and weaknesses whereas some variables are related to their exceptions from the government agencies, the activities, which are or may be controlled by the government and can play an important role in promoting the export of handloom products from India. The opinions of the exporters were recorded on a five point Likert scale. The exporters' survey was done with 119 respondents from Tamil Nadu, Delhi, Haryana and Uttar Pradesh. The exporters' questionnaire contains 45 items, altogether. These variables were first of all tested for their significance through one-sample t-test. Except a few variables namely ability to execute low volume order, logistic problems and difficult export procedure, all the other variables were found to be significant at $\mathrm{p}<.05$. For testing the internal consistency of data, Cronbach's alpha for all the remaining items was calculated and found to be 0.875 which is in the acceptable range and considered appropriate for further analysis.

These variables were used for ascertaining the strategy for export of handlooms. In order to arrive at a few number of strong predictor variables, all the variables were subjected to multiple regression analysis keeping the opinion of the exporters that exporting had contributed to the sales growth of the firm, as the dependent variable. The independent variables being the items related with the areas of the efforts of the exporters, the support system of the government and a few controllable environmental factors. In using the stepwise multiple regression analysis on these variables, the regression model thus obtained is shown in Table 4. Variables found place in the regression model having $\mathrm{R}^{2}$ of .967 and adjusted $\mathrm{R}^{2}$ value of .960 . The model, which explains $96 \%$ of the variance is statistically significant $(\mathrm{F}=150.581, \mathrm{p}<.001)$. The Durbin-Watson statistics of 1.909 shows the independence of observation.

The model shown in Table 4 shows the unstandardized and standardized beta coefficient and t-value for each predictor variable with $\mathrm{p}$-value. To assess the effect of multicollinearity, the collinearity statistics of Tolerance and Variance Inflation Factor (VIF) are also calculated and given in the table. The variables, which are found significant in the stepwise multiple regression model are discussed here.

The first variable to enter the regression model is meeting the internationally recognized quality standards. The handloom exporters who do well find it extremely important that the handloom products should meet the internationally recognized quality standards such as ISO series, Japanese standards, US standard and European standard etc. $(B=0.359$, Beta $=0.661, t=14.218)$. In other words, the success of exporters can be attributed to their concern for the quality. 
Table 4: Multiple Regression Analysis of Handloom Exporters Survey

Dependent Variable: Contribution of Exporting in Firms' Sales Growth

\begin{tabular}{|c|c|c|c|c|c|c|}
\hline \multirow[t]{2}{*}{$\begin{array}{l}\text { Independent } \\
\text { Variables }\end{array}$} & \multirow[t]{2}{*}{$\begin{array}{l}\text { Unstandard } \\
\text { ized B }\end{array}$} & \multirow[t]{2}{*}{$\begin{array}{c}\text { Standardized } \\
\text { Beta }\end{array}$} & \multirow[t]{2}{*}{$\mathbf{t}$} & \multirow[t]{2}{*}{$\begin{array}{c}\text { p- } \\
\text { value }\end{array}$} & \multicolumn{2}{|c|}{$\begin{array}{l}\text { Collinearity } \\
\text { Statistics }\end{array}$} \\
\hline & & & & & Tolerance & VIF \\
\hline $\begin{array}{l}\text { Meeting } \\
\text { international } \\
\text { quality }\end{array}$ & 0.359 & 0.661 & 14.218 & 0.000 & 0.156 & 6.404 \\
\hline $\begin{array}{l}\text { Depend on buyers } \\
\text { for new ideas }\end{array}$ & 0.135 & 0.243 & 10.561 & 0.000 & 0.639 & 1.565 \\
\hline $\begin{array}{l}\text { Market } \\
\text { information }\end{array}$ & -0.240 & -0.387 & -8.305 & 0.000 & 0.156 & 6.415 \\
\hline $\begin{array}{l}\text { Knowledge of } \\
\text { import regulation }\end{array}$ & -0.505 & -0.822 & -0.548 & 0.000 & 0.211 & 4.739 \\
\hline Strategic options & 0.316 & 0.641 & 18.323 & 0.000 & 0.276 & 3.623 \\
\hline $\begin{array}{l}\text { Lack of discipline } \\
\text { among weavers }\end{array}$ & -0.750 & -0.782 & $\begin{array}{c}- \\
22.233\end{array}$ & 0.000 & 0.273 & 3.664 \\
\hline $\begin{array}{l}\text { Developing eco- } \\
\text { friendly products }\end{array}$ & 0.398 & 0.657 & 15.203 & 0.000 & 0.181 & 5.522 \\
\hline $\begin{array}{l}\text { Searching new } \\
\text { market }\end{array}$ & 0.105 & 0.172 & 5.634 & 0.000 & 0.364 & 2.746 \\
\hline $\begin{array}{l}\text { Promotional } \\
\text { measures }\end{array}$ & 0.407 & 0.797 & 17.039 & 0.000 & 0.155 & 6.468 \\
\hline $\begin{array}{l}\text { Knowledge of } \\
\text { traditional living } \\
\text { system }\end{array}$ & -0.129 & -0.190 & -4.711 & 0.000 & 0.208 & 4.810 \\
\hline $\begin{array}{l}\text { Communication } \\
\text { with buyers }\end{array}$ & 0.239 & 0.298 & 5.689 & 0.000 & 0.123 & 8.119 \\
\hline $\begin{array}{l}\text { Knowledge about } \\
\text { retail abroad }\end{array}$ & -0.291 & -0.587 & $\begin{array}{c}- \\
14.681\end{array}$ & 0.000 & 0.211 & 4.732 \\
\hline $\begin{array}{l}\text { Maintaining } \\
\text { unique image }\end{array}$ & -0.085 & -0.162 & -2.750 & 0.007 & 0.098 & 10.231 \\
\hline $\begin{array}{l}\text { Creating image of } \\
\text { 'Brand India' }\end{array}$ & -0.209 & -0.48 & -9.331 & 0.000 & 0.126 & 7.946 \\
\hline $\begin{array}{l}\text { Creating brand } \\
\text { image }\end{array}$ & 0.167 & 0.344 & 8.209 & 0.000 & 0.192 & 5.210 \\
\hline Trading Pattern & -0.345 & -.174 & -5.624 & 0.000 & 0.355 & 2.820 \\
\hline Value addition & -.058 & -0.122 & -2.511 & 0.000 & 0.171 & 5.859 \\
\hline $\begin{array}{l}\text { Developing } \\
\text { cheaper varieties }\end{array}$ & 0.065 & 0.117 & 3.249 & 0.002 & 0.259 & 3.867 \\
\hline $\begin{array}{l}\text { Differentiated } \\
\text { pricing strategy }\end{array}$ & -0.056 & -0.094 & -2.831 & 0.006 & 0.305 & 3.275 \\
\hline
\end{tabular}




\begin{tabular}{|l|l|l|l|l|c|}
\hline & \multicolumn{1}{|c|}{$\begin{array}{c}\text { Sum of } \\
\text { Squares }\end{array}$} & \multicolumn{1}{|c|}{ Df } & $\begin{array}{c}\text { Mean } \\
\text { Square }\end{array}$ & F & Sig. \\
\hline Regression & 28.412 & 19 & 1.495 & 150.581 & 0.000 \\
\hline Residual & 0.983 & 99 & 0.010 & \multicolumn{2}{|c}{} \\
\cline { 1 - 5 } Total & 29.395 & 118 & \multicolumn{3}{|c}{} \\
\hline
\end{tabular}

$\mathrm{R}^{2}=0.967 ; \quad$ Standard Error of Estimate $=0.100$

Adjusted $\mathrm{R}^{2}=0.960 \quad$ Durbin-Watson 'd' statistics $=1.909$

In the prevailing export business of today, the exporters invariably depend on buyers for new ideas to be converted into exportable products. Their success depends upon their capability to convert the buyers ideas into actual products with least deviation $(\mathrm{B}=0.135$, Beta $=0.243, \mathrm{t}=10.561)$. Therefore, in export of handloom, the buyers are the main source of new ideas that guide the product development which bring opportunities of new bulk orders for the handloom exporters. Market information plays an important role in handloom export as another significant variable to enter in the regression model is the importance of market information $(B=-0.240$, Beta $=-0.387, t$ $=-8.305)$. From the above statistics it can be concluded that those exporters who are either not very successful or struggling for success feel the need of market information to be provided by the government. Therefore, the government can play a very important role by way of providing information about the market to the small exporters and those who struggle for getting success in the business of handloom exports. The very important aspect in the success of the export business of handloom is the knowledge about the importing countries and the structure of market there. Those handloom traders, for whom exporting does not contribute much to their sales growth adjudged the knowledge of import regulations of the importing countries as extremely important. ( $\mathrm{B}=$ -0.505 , Beta $=-0.822, \mathrm{t}=-20.548)$. The less successful or struggling handloom exporters acknowledge the importance of the knowledge of traditional living system also, of the importing countries $(\mathrm{B}=-0.129$, Beta $=-0.190, \mathrm{t}=-4.711)$.

Such handloom exporters, also feel that for success in export of handloom, the information about the market structure of the importing country, the way the Indian handloom products are marketed there, the style of presentation of the product in the retail outlets, the promotion and the pricing etc. are crucial $(B=-0.291$, Beta $=-0.587, t=$ -14.681). Therefore, these are the important factors for the struggling handloom exporters, though may not be that much significant for the successful exporters. In the current scenario the strategic alliances in the international business such as joint venture, collaboration and counter trade etc are considered to be desirable among the exporters (B $=0.316$, Beta $=0.641, \mathrm{t}=18.323)$. The successful exporters, feeling the importance of such alliances, find these options attractive. This gives a clear scope for big players to 
enter into such arrangements in the global market place for better hold in the market. The attitude of weavers also has a bearing on the success in the export business of handloom products. The exporters who could not do well in their export growth, hold the undisciplined attitude of weavers responsible for their poor show $(\mathrm{B}=0.750$, Beta $=$ $0.782, \mathrm{t}=-22.233)$. The supply chain members including weavers are yet to realize the importance of product quality, completing the orders with correct quantity and at specified time. Another important area of product development is the development of eco-friendly products, which enters the regression model. The global market is witnessing an increasing demand for eco-friendly products such as products made of natural dyes, organic cottons and products having those ingredient which cause no harm to user's body and skin $(\mathrm{B}=0.398, \mathrm{~B}=0.657, \mathrm{t}=15.203)$.

A major share of India's export of handloom products is held by USA and EU countries. A majority of handloom exporters feel that apart from retaining the existing markets, the search should always be focused on finding scope of markets with new consumer segments and new geographical locations on the globe. $(\mathrm{B}=0.105$, Beta $=$ $0.172, \mathrm{t}=5.634)$. Handloom exporters may, therefore, try to explore the markets such as Latin American and Middle East countries etc., which are less tried by them so far. According to the Indian handloom exporters, their success depends upon the promotion of Indian handloom in the global market. The government's promotional support such as organizing buyer-seller meet; facilitating participation in international trade fairs and exhibitions; and media publicity help in increasing the performance of Indian handloom exporters $(\mathrm{B}=0.407$, Beta $=0.797, \mathrm{t}=17.039)$. Apart from the above specified measures, creation of 'Brand India' is also sought by the exporters, which may enhance the demand of Indian handloom indirectly in the global market place $(B=-0.209$, Beta $=$ $0.484, \mathrm{t}=-9.331$ ). Therefore, government should pay more attention towards building the image of 'Made in India' label to instill confidence among the international consumers. Success in export business, in general depends on the timely, speedy, correct and effective communication with the buyer as communication is another predictor variable in the multiple regression model $(\mathrm{B}=0.239$, Beta $=0.298, \mathrm{t}=5.689)$. Handloom exporters should, therefore, pay due attention to communication aspect in their business. The handloom exporters realize the importance of creating the image of their own brand in the export market. Those exporters who perform well attribute the credit of their success in the export business to their effort to the creation of the image of their brand $(\mathrm{B}=0.167$, Beta $=0.344, \mathrm{t}=8.209)$. Therefore, there is a lot of scope of creating image of the brand which can be done successfully by the big export houses who have access to the resources in plenty. Export of handloom can be promoted if some resourceful entrepreneurs venture in the export of handloom products, and mobilize their 
resources in the direction of building their brand image. Few of the exporters have already initiated their effort through creating their own catalogue. Trading pattern is another predictor variable for the growth of handloom export. Those exporters who have their own manufacturing base do better than those exporters who do not have production base. $(\mathrm{B}=0.345$, Beta $=0.174, \mathrm{t}=5.624)$. It is, therefore, advisable to the handloom exporters to create their own production facility for the better grip over the export market. Apart from the above significant predictor variables there are a few other variables which are figured in the multiple regression model but not significant at $\mathrm{p}<$ .001. These variables are maintaining unique image of Indian handloom products; value addition in the handloom products; developing cheaper varieties; and keeping different pricing for different markets.

\subsection{Conclusion}

The multiple regression analysis of the data obtained from the handloom exporters on various export related variables leads to several findings. It was found that meeting the internationally recognised quality standardisation is one of the most important prerequisite for success in export of handloom products. Further the success in export of handloom depends upon the correct understanding of buyers' ideas and instruction. It means that the buyers' ideas, if converted into actual product successfully to the satisfaction of the buyer, fetch better results. It was also found that the exporters pay attention to the development of eco-friendly products for getting success in their export business, such as the product made out of natural dyes, organic cotton etc. The exporters who have their own production base find exporting contribute significantly to their sales growth. The exporters feel that the governmental support; for export promotion such as buyer-seller meet, exhibition and trade shows etc.; is essential. The efforts of exporters on creating the image of their brand in the minds of overseas buyers produce positive results. The strategic alliances in the export business such as joint venture, collaboration, and countertrade etc. can be utilised by the exporters for even better penetration in the overseas market.

The exporters favour the intense efforts towards exploration of untapped global market for the expansion of the export of handloom. The effective and speedy communication with buyer is an essential for the success in export business. The exporters who are not doing well expressed the need of getting market information such as the living system and import regulations of the importing countries and the structure of the market there. This information can be provided by the government agencies to the handloom exporters. This category of exporters also feels that the government should 
launch promotion drive to establish the image of 'Made in India' brand globally, which may help them selling their products in the overseas market. The behaviour of handloom weavers affects the performance of the exporters negatively. The handloom exporters lament the behaviour of weavers for not realising the importance of manufacturing and delivering the products of agreed quality and at agreed time.

One important dimension of the study is to find out how to make handloom products competitive in the global market. The presence of the handloom products in the overseas market has been remarkable. But the globalisation has thrown open various challenges to the handloom sector. Through this study an attempts has been made to gauge the minds of the handloom exporters and their preparedness for the future course of action. The recommendations with regard to the export strategies for handloom products are given here.

Appreciating the growing concern for quality of textile in global market, meeting the standards of the internationally accepted quality norms, is one of the most important requirement for success in export market. Handloom exporters must, therefore, adopt the mechanism to adhere to the international quality standardization such as ISO, Japanese standard, US standard or UK standard etc. By establishing own production base, the handloom exporters should have the ability to understand the buyers instruction correctly and transform the buyers ideas into reality on the actual fabric with minimum deviation from the ideas originally conceived by them. As the consumers in global market are becoming increasingly conscious towards environmental issues, more attention should be paid towards the use of natural dyes and organic cotton etc. which do not harm the human bodies and at the same time do not cause harm to the environment.

The information about the geography, demography, and economy of the importing countries are crucial. Moreover the market related information is also helpful for the exporters. The handloom exporter must, therefore, pay attention to acquiring such information by them. Government and the government agencies may also offer their assistance to the exporters in this regard. Handloom exporters, realising the importance of communication, should pay due attention to communicate correctly, convincingly, clearly, timely and swiftly to their buyers. Handloom exporters should try to build an image of their brand with the buyers for the long term benefits on certain parameters such as quality, price and delivery.

Establishing the strategic alliances such as joint venture, countertrade and collaboration etc. with the overseas firms also constitutes the success prescription for the handloom exporting firms, because in this manner the benefits of the firms in the other countries can be linked with more strength. The handloom exporters should put their 
efforts in exploration of new markets, be it a new consumer segment or new geographic locations on the globe apart from their existing markets, which is untapped so far.

Government's role in enhancing the competitiveness of handloom in global market is much sought after. The government must concentrate more on providing the avenues of business promotion to the handloom exporters such as buyer seller meets, fairs and exhibition etc. The government should also work for building the image of 'Brand India' in the international market by launching the campaign through appropriate media. The governments' role is also desirable in providing useful information with regard to the geographic, economic and demographic characteristics of importing countries to the handloom exporters.

A whole export culture needs to be developed through the supply chain so that all the channel members including weavers realise the importance of honouring the commitments made to the buyers with regard to quality, quantity and the delivery schedule etc. in the export business; and the consequences of dishonouring them. The exporters taking the benefit of the government initiatives should enhance their efforts in tapping the new markets and value addition on the conventional products.

\subsection{Limitation of the study and direction for further research}

No study can be complete, comprehensive and free from imitations in all respect because of financial and intellectual resource constraints. Just like any other study, this research too has certain limitation. This study is confined to only two regions of India namely South and North. The exporters' survey is done among the exporters of Tamil Nadu in South; and Delhi, Haryana and Uttar Pradesh in North. The other regions of Western and Eastern India remained uncovered in this survey, due to various constraints. Further, various dimensions of marketing mix were not studied very minutely. The most important limitation of the study is that the views of the foreign buyers and importers of handloom products could not be gathered, which could have been very useful for crafting the export marketing strategy for handloom products. Keeping in mind the above limitations further studies in future can be undertaken to suggest marketing strategies for the export of Indian handloom products.

\section{References}

Aulakh, P. S., Kotabe, M. \& Teegen, H. (2000). Export strategies and performance of firms from emerging economies: Evidence from Brazil, Chile and Mexico. Academy of Management Journal 43(3): 342-361. 
Bhagirathy, A. \& Sengupta, N. (2003). Surviving in a globalising world. Seminar, 523: 5862.

Christopher, S. B. \& Nagarajan, R. (2002). Indian cotton handloom exports in a globalised economy. In Soundarapandiyan, M. (Ed.), Small Scale Industries Vol. I, New Delhi: Concept Publishing Company.

Clawson, C. J. (1974) Fitting branch location, performance standards and marketing strategies to local conditions. Journal of Marketing 38(January): 8-14.

Cooper, D. R. \& Schindler, P. S. (2006). Business Research Methods, New Delhi: Tata McGraw Hill Publishing Company Limited.

Crick, D. \& Katsikeas C.S. (1995). Export practices in the UK clothing and knitwear industry. Marketing Intelligence \& Planning 13(7): 13-22.

de la Torre, J.R. (1971). Exports of manufactured goods from developing countries: Marketing factors and the role of foreign enterprise. Journal of International Business Studies, 2(1): 26-39.

EXIM Bank (2000). Indian Handloom- A Sector Study, Occasional Paper No. 79.

Fitzgerald, B. \& Monson T. (1989). Preferential credit and insurance as means to promote exports. The World Bank Research Observer, 4(1): 89-114.

Government of India (2012-13). Annual Report 2012-13, New Delhi: Ministry of Textiles.

Gulati, N.H. (1998). The handloom. Khadi Gramodyog 44(5): 179-181.

Gurumoorthy, T. R. \& Rengachari, N. R. (2002). Problems of handloom sector. In Soundarapandiyan, M. (Ed.), Small Scale Industries Vol. I, New Delhi: Concept Publishing Company.

Hair, J.F. Jr., Anderson, R.E., Tatham, R.L. \& Black, W. C. (2006). Multivariate Data Analysis, New Delhi: Pearson Education. 
50 | FOCUS: Journal of International Business, Vol. 2, Issue 1

Housego, J. (2003). Market realities. Seminar, 523: 54-57.

Iyer, S. M. (2000). An ancient industry looks to the new millennium. Yojana 44(7): 3637.

Karunakaran, R. \& Karthikeyan, M. (2002). Consumers' behaviour towards handloom textiles; A study. In Soundarapandian, M. (Ed.), Small Scale Industries Vol. I, New Delhi: Concept Publishing Company.

Kasturi, P. B. (2006). Story of many threads: A case study of DESI. Economic and Political Weekly 41(31): 3369-71.

Kothari, C. R. (2004). Research Methodology: Methods and Techniques. New Delhi: New Age International Publishers.

Kumar, N. (1983). Export promotion of handloom goods. Indian Journal of Marketing July-August: 9-10.

Leible, M. \& Roy, T. (2003). Handmade in India- Preliminary analysis of craft producers and craft production. Economic and Political Weekly 38(51\& 52): 5366-76.

Lisboa, A., Skarmeas, D., \& Lages, C. (2013). Export market exploitation and exploration and performance: Linear, moderated, complementary and non-linear effects. International Marketing Review, 30(3): 211-230.

Malhotra, N.K. (2005). Marketing Research. New Delhi: Pearson Education.

Mehta, R. (2004). Success story. Humanscape 11(7): 17-18.

Modak, S. (2006). Weaving customers' dream: A case study of Fabindia. Economic and Political Weekly 41(31): 3367-68.

NABARD (2002), Growth and Prospects of Handloom Sector of India, Occasional Paper No. 22.

National Council of Applied Economic Research (2009-10), Handloom Census of India. 
Plumlee, T. M. and Little, T. J. (2006). Proactive product development, integrating consumer requirement. International Journal of Clothing Science and Technology 18(1): 53-66.

Pradhan, J.P. (2008). Indian Multinationals in the World Economy: Implications for Development, New Delhi: Bookwell Publisher.

Pradhan, J.P. \& Sahu P.P. (2008), Transnationalization of Indian Pharmaceutical SMEs, New Delhi: Bookwell Publisher.

Pradhan, J.P., Zohair M., \& Alagavadi M.V. (2013). Regional policies, firm characteristics and exporting in the Indian state of Karnataka. Foreign Trade Review, 48(1): 45-81.

Rajam, M. P. (2004). Shifting designs. Humanscape, 11(7): 15-16.

Rao, K. R. \& Subramanyam, G. (1995). Crisis in the handloom industry: Some solutions. Kurukshetra, September: 36-38.

Rao, K. R. (1997). The dynamics of handloom industry. SEDME Journal, 24(4): 13-19.

Richey, R. G. \& Myers, M. B. (2001). An investigation of market information use in export channel decisions. International Journal of Physical Distribution \& Logistic Management, 31(5): 334-353.

Roy, D. K. (1993). Impact of incentives on export performance of Bangladesh: A preliminary assessment. Bangladesh Development Studies, 21(2): 25-44.

Thakur, A. (1995). A framework for analysing the handloom industry. Vikalpa, 23(3): 77-81.

Thillinayagan, N. \& Muruganandan, P. (2002). Export promotion in handloom industry: A case study of HEPC. In Soundarapandian, M. (Ed.), Small Scale Industries Vol. II, New Delhi: Concept Publishing Company. 
52 | FOCUS: Journal of International Business, Vol. 2, Issue 1

Toften, K. \& Olsen S. O. (2003). Export market information use, organisational knowledge, and firm performance: A conceptual framework. International Marketing Review, 20(1): 95-110.

Toften, K. \& Rustad, K. (2005). Attributes of information quality of export market assistance: An exploratory study. European Journal of Marketing, 39(5/6): 676-695.

Venkatachalam, A. (1992). Handloom exports needs quality management. Southern Economist, 31(20): 9-11.

Vishwanath, V. (2004). How the West was won? Humanscape, 11(7): 14-15.

Zohair, M. (2012). Export of Indian handloom. International Journal of Business, Management and Social Science, 2(1/2): 4-10.

\section{Web references}

http://www.ibef.org/exports/handloom-industry-india.aspx

http://www.hepcindia.com/government.php 